\title{
H2BC12 Gene
}

National Cancer Institute

\section{Source}

National Cancer Institute. H2BC12 Gene. NCI Thesaurus. Code C162947.

This gene plays a role in histone-mediated processes and humoral antimicrobial responses. 